Original Research Paper

\title{
Frequency, Substance and Procedural Shortcomings of State Level Impeachment Campaigns in an Emerging Federal Democracy
}

\author{
Ibraheem Oladipo Muheeb \\ Centre for Black and African Arts and Civilization, Nigeria
}

Article history

Received: 10-12-2015

Revised: $15-06-2016$

Accepted: 17-06-2016

Email: ibraheem_muheeb@yahoo.com

\section{Introduction}

The 1999 Constitution of the Federal Republic of Nigeria provides for a bicameral legislature of two chambers, the Senate and House of Representatives at the national level and a unicameral assembly, a State House of Assembly in each of the thirty-six (36) States of the federation. Section 4 of the Constitution encompasses the principle of separation of powers and checks and balances within the context of legislatureexecutive relations. The entrenchment of separation of Impeachment

\begin{abstract}
Nigeria's 1999 Constitution encompasses separation of powers and checks and balances. It enjoins institutional autonomy in specific spheres, and systemic mutual inter-dependence of the legislature, executive and judiciary. The legislature has unfettered right to be self-regulatory including intra-institutional changes in leadership. Such right must be exercised responsibly and in conformity with the Constitution. Erring executive official could be impeached by the legislature in collaboration with the judiciary exclusively for acts and omissions amounting to gross misconduct. The scanty details without clearly defined grounds for impeachment in the constitution put the executive at the mercy of the legislature, which exercises exclusive discretion on what constitute "gross misconduct". Impeachment as a process that involves setting aside the will of the electorate is too crucial a legislative matter of course, to be undertaken arbitrarily. In Nigeria's conflictual distributive and transactional Fourth Republic politics (1999-2015), pliable and reckless legislatures have launched intra and inter-institutional impeachment campaigns on frivolous grounds. Controversial impeachments have further enhanced the prominence of legislatures. The preponderance of externally induced leadership tussle questions legislatures' capacity to be self-regulatory amidst other vices. Executives' initial autocratic tendencies vis-à-vis denial of legislatures' right of scrutiny is waning with increasing consciousness of the consequences of recourse to impeachment among other gains. This paper highlights the frequency, politics, substance and procedural shortcomings of impeachment campaigns. Theory of separation of powers suffices. Given its potential in political and power contestations, impeachment would continue to feature as bargaining chip as the system of rule progresses.
\end{abstract}

Keywords: Nigeria, Constitution, Separation of Powers, Legislature and

powers among the three arms of government, the legislature, the executive and the judiciary accounts for the limit on the exercise of powers that should characterize legislative-executive relations. Separation of powers entails a relationship of checks and balances between the legislature and the executive, implying that neither should be in a position to act with impunity. Separation of powers, functions and personnel inherent in a representative regime constitutionally limits executive influence in the legislature. It nonetheless recognises the relative independence of the judicial arm 
of government in all circumstances for public good (Muheeb, 2016a; Hague and Harrop, 1992; Nyong, 2000; Lijphart, 1992). Sections 60 and 101 granted the legislature at the national and state levels concurrent rights to be self-regulatory. This is notwithstanding the fact that section 105(3) granted the Governor power to issue a proclamation for the holding of the first session of the House of Assembly or for its dissolution as and when necessary. These provisions are similar to sections 58 and 64 as regards presidential intervention in the lawmaking process as well as the issuance of a proclamation for the holding of the first session of the National Assembly or the dissolution of same at the expiration of a period of four years commencing from the date of the first sitting of the legislature. Section 4(17) clearly defined the legislative powers of the National Assembly and the State Houses of Assembly. In sum, Chapter V, sections 47-89 and 90-129 outline details on the composition and staff of the legislature, procedure for summoning and dissolution of the legislature, qualification for membership and right of attendance, election into the legislature as well as legislative powers and control over public funds including right to conduct investigations and to seek evidence within the confines of legislative oversight.

Sections 69 and 110 of the Nigerian Constitution empower constituents to recall any erring representatives serving in the national or subnational legislature while sections 143 and 188 prescribe impeachment of erring elected officials in the executive arm of government namely, the President, the Vice President, the Governor and the Deputy Governor respectively. Impeachment is to be carried out by the legislature in collaboration with the judiciary exclusively for acts and omissions amounting to gross misconduct in the performance of the functions of the office. Sections143(11) and 188(11) summarily define "gross misconduct", as a grave violation or breach of the provisions of the Constitution or a misconduct of such nature as amounts in the opinion of the National Assembly or a State House of Assembly to gross misconduct. The noticeable loopholes arising from the scanty details on impeachment in the Nigerian constitution without highlighting the specific grounds for removing elected executive official from office left the exact definition of impeachable offenses open to interpretation by the legislature. Thus, the constitution put the executive at the mercy of the legislature as the latter could in its estimation and opinion exclusively determine what amounts to "gross misconduct". Suffice it to stress that pliable and reckless legislatures may have harped on the seeming constitutional lacuna to impeach on frivolous grounds. The recurring cases of impeachment campaign fraught with controversies underscore this inadequacy. Impeachment thrived either on account of inexperience, power struggle, political contestation or the typically conflictual distributive
Nigerian politics that thrived during the period under review (Muheeb, 2016a; 2015; Onyekpere, 2014; Solomon, 2014; Ukumba, 2014; Ogaziechi, 2014).

The need to focus on specifics is crucial. Hence, this paper interrogates the frequency of state level impeachment campaigns in Nigeria's Fourth Republic, 1999-2015. To borrow from Scott Desposato, this approach was borne out of the understanding that subnational legislatures in a federation like Nigeria are crucial 'mini-laboratories' for observing and explaining how legislative institutions work in different contexts. Insights from the experiences of state legislatures may be useful to improve the legislature's overall productivity at the national level (Desposato, 2004). This paper is a follow-up to existing works on legislative studies in Nigeria by this author. It particularly took advantage of the author's earlier study on subnational legislature with a report on the performance of a subnational legislature in representation and oversight between 1999 and 2011. Author's knowledge of the essentials of legislative institutionalization namely, autonomy, internal complexity and universalism were handy in contextualizing the theoretical framework. Author made deduction of the legislative environment and the circumstances of political exchanges in which lawmakers operates vis-à-vis the outcomes of legislative practices during the period under review. Case study and content analysis were adopted with data on constitutional powers and state level legislative practices drawn from libraries and the media. Quantitative data were graphically presented, while qualitative data were content analyzed (Muheeb, 2015). Findings reveal that impeachment campaigns actually put many subnational legislatures in the spotlight, whereas the legislature's critical areas of performance namely, representation, lawmaking and oversight should ordinarily provide the basis for the assessment of its performance. Impeachment campaigns were rife across many states, prompting sudden changes in States Houses of Assembly leadership at short notices amidst arbitrary deployment of impeachment against State executives.

Analysis and discussion in this paper revolves around the objectives of interrogating the frequency politics, substance and procedural shortcomings of state level impeachment campaigns; exploring the peculiarities of subnational legislative environment in Nigeria to understand how legislative institutions operate in different contexts; and proffer suggestions on how to check future arbitrary deployment of impeachment. This paper does not intend to run a comprehensive inventory/history of the many challenges of representation or the intractable inter and intra-party crises in the on-going Fourth Republic; neither does it intend to embark on partial or comprehensive assessment of the legislature and legislative practices already 
discussed elsewhere (Muheeb, 2016b). The Nigeria's Fourth Republic commands greater elasticity than most other issues of its kind as an ongoing discourse, hence, the need to prioritize and be subject-specific to effectively appreciate the substance and essence of crucial issues of democratic and party politics significance. Besides, similar single-subject-area titles with relative coverage by this author include: "The Extremes and Absurdities of Impeachment and Impeachment Proceedings"; "Power Struggle, Rule of Law and the Consolidation of Representative Government"; "Executive Presidency and Institutional Manipulation in an Emerging Federal Democracy"; "The Subnational Legislature and the Challenge of Vertical Relationship in Nigeria"; "Fragmented Assemblies and the Constraint of Institutional Instability"; and "The Legislature and Party Politics in the Nigeria's Fouth Republic".

\section{Report of Findings}

The tables below represent inventories of reported impeachment campaigns across State assemblies. Although they are by no means exhaustive; yet, the tables reveal widespread affliction of systemic and institutional stability. Following (Onyekpere, 2014; Solomon, 2014; Ukumba, 2014; Ogaziechi, 2014), impeachment was handy to settle personal scores among political actors. It was appropriated as synonymous with oversight and anti-corruption device deployed in the power struggle that constituted a major constrain to effective representative governance. Intra-institutionally, Speakers and Deputy Speakers fell victim of impeachment campaigns by their colleagues on sundry allegations of misdemeanour. These include inaccessibility, lack of administrative acumen, gross incompetence, arrogance, constant romance with the executive and the pursuit of selfish agenda at the expense of institutional cohesion among others. A number of speakers were impeached for acting in manners that were incongruent with official ethos, hobnobbing with the executives of their respective states mainly for selfish purposes. In addition to overbearing tendencies, some of these principal officers were accused of exhibiting dispositions that demeaned and diminished the respect and dignity of their members. Inter-institutionally, impeachment spilled over to the State Governors and their Deputies. In addition to State Governors' incessant intransigence, allegations abound that the presidency was the unseen hand behind many State level impeachment campaigns against States' executive particularly those recorded at the twilight of the successive general elections.

However, lack of autonomy, inadequate human and financial resources and inexperience on the part of lawmakers among other legislative institutionalisation problems took their tolls on State legislatures, many of which equated oversight with impeachment. State assemblies were also enmeshed in national intra-party politics, which percolated into the respective State assembly chambers. Members were factionalised around political gladiators. Conversely, impeachment has help to keep many State Governors on their toes as they become wary of such extreme measure against them. In addition to giving due recognition to the institution of the legislature, State executives have had to curtail some of their excesses and inordinate pursuits. Perhaps, the development has the propensity to help sanitize the polity in the long run. Although it attracted pockets of public outcry when it appeared seemingly abused, impeachment has sent strong message on its efficacy, questioning the technical incompetence of victims, embezzlement of public funds, sheer display of arrogance by elected representatives as well as selfish and undue legislative-executive fiasco among others.

\section{Frequency of Reported State-Level Impeachment Campaigns Nationwide 1999-2015}

\section{Discussion of Findings}

\section{Gains and Pains of Intra and Inter-Institutional Impeachment Campaigns}

There were seventy-seven reported cases in all (North-Central 11, North-East 8, North-West 8, SouthEast 18, South-South 14 and South-West 15). Across the geo-political zones, inter and intra-institutional impeachment took similar courses of actions. Following Mgbe (2013), a politician that is confronted with impeachment either resigns as a sort of plea bargain or allowed the impeachment process to run its course and this was an option taken by a number of principal officers across State assemblies as Table 1-6 reveal (see numbers 2 and 13 in Table 1 , number 6 in Table 2, number 4 in Table 3, number 7 in Table 5 and number 1 in Table 6). Resignations were borne out of intrainstitutional politics and compromises. Electorates were also shortchanged in impeachment processes given the speed and frequency that left no room for consultation if and where necessary. For example, a vastly unpopular action, Governor Obi's (see number 8 Table 4) purported impeachment and subsequent replacement by his deputy caught the electorate unaware (Mgbe, 2013). Subnational legislatures were also manipulated particularly by the federal executive to achieve personal political agenda and in disregard for constitutional provisions guiding impeachment proceeding. To this, Onuoha queried the former Ekiti Assembly for disregarding a subsisting ruling by the Chief Justice of Nigeria against the impeachment process initiated against governor Ayodele Fayose (see number 3 Table 6) at the time. Other than acting out the script handed down by external forces, the lawmakers' effrontery was arbitrary (Onuoha, 2006). 
Table 1. North Central

\begin{tabular}{|c|c|c|c|c|c|}
\hline Year & State & Institution & Victims officials & Grounds of impeachment/remarks & Outcome \\
\hline August 2000 & Benue & In-house & Speaker & Inefficiency & Successful \\
\hline November 82012 & Benue & In-house & Speaker & $\begin{array}{l}\text { Financial impropriety and misrepresentation of the } \\
\text { members to the executive arm of government }\end{array}$ & Resigned \\
\hline September 242013 & Kaduna & In-house & Speaker & Incompetence and alleged gross misconduct & Successful \\
\hline 1999-2003 & Kogi & Executive & Governor & & Unsuccessful \\
\hline October 162012 & Kogi & In-house & Speaker & Secret session by 12 instead of 17 of 25 members & Successful \\
\hline May 2015 & Niger & In-house & Speaker & Politics/allegation of misconduct & Successful \\
\hline October 22013 & Plateau & In-house & Speaker & Weak and Subservience & Resigned \\
\hline November 132006 & Plateau & Executive & Governor & $\begin{array}{l}\text { Charges of Corruption, misconduct, misappropriation } \\
\text { of funds and money laundering by the EFCC }\end{array}$ & Successful \\
\hline October 22013 & Plateau & In-house & Deputy speaker & Weak and Subservience & Successful \\
\hline $1999-2003$ & Taraba & Executive & Governor & Dictatorial tendencies & Unsuccessful \\
\hline October 42012 & Taraba & Executive & Deputy governor & Diversion of public funds for private use/Abuse of office & Successful \\
\hline April 222013 & Taraba & In-house & Speaker & Financial misappropriation & Successful \\
\hline November 242014 & Taraba & In-house & Speaker & Personal reasons & Resigned \\
\hline November 232015 & Taraba & In-house & Speaker and deputy & Diverted members allowances, incited disunity and abuse of office & Successful \\
\hline
\end{tabular}

Table 2. North East

\begin{tabular}{|c|c|c|c|c|c|}
\hline Year & State & Institution & Victims officials & Grounds of impeachment/remarks & Outcome \\
\hline 2015 & Adamawa & In-house & Speaker and deputy speaker & Loss of confidence in the leadership & Successful \\
\hline February 2009 & Adamawa & Executive & Governor & $\begin{array}{l}\text { Abuse of office, financial } \\
\text { mismanagement and corruption }\end{array}$ & Unsuccessful \\
\hline December 72011 & Adamawa & In-house & Speaker and deputy & $\begin{array}{l}\text { Incompetence and lack of } \\
\text { administrative acumen }\end{array}$ & Successful \\
\hline July 2014 & Adamawa & Executive & Governor & $\begin{array}{l}\text { Abuse of office, Misappropriation, } \\
\text { financial mismanagement }\end{array}$ & Successful \\
\hline February 2011 & Bauchi & In-house & Speaker & $\begin{array}{l}\text { Non-performance and lack of } \\
\text { purposeful leadership }\end{array}$ & Successful \\
\hline August 132009 & Bauchi & Executive & Deputy governor & $\begin{array}{l}\text { Politics and collected two different estacodes } \\
\text { for a single trip, granted approvals, approved } \\
\text { contracts beyond his limit }\end{array}$ & Successful \\
\hline August 2007 & Bauchi & In-house & Speaker & $\begin{array}{l}\text { Forced to resign barely three months as } \\
\text { Speaker after he violated a resolution by the } \\
\text { House stopping any lawmaker in the state } \\
\text { from going to the Government House. }\end{array}$ & Resigned \\
\hline Jan/Feb 2012 & Borno & In-house & Speaker & $\begin{array}{l}\text { Inaccessibility, arrogance and } \\
\text { constant romance with the executive }\end{array}$ & Successful \\
\hline
\end{tabular}

Table 3. North West

\begin{tabular}{|c|c|c|c|c|c|}
\hline Year & State & Institution & Victims officials & Grounds of impeachment/remarks & Outcome \\
\hline $99 / 2000$ & Kano & In-house & Speaker and deputy & & Successful \\
\hline December 192011 & Kano & In-house & Speaker & Gross incompetence & Successful \\
\hline & Katsina & In-house & Speaker & Failure of the principal witness to appear before the house panel & Unsuccessful \\
\hline July 112012 & Katsina & In-house & Deputy speaker & Politics/allegation of misconduct & Resigned \\
\hline November 272014 & Kebbi & In-house & Speaker & Controversial circumstances & Successful \\
\hline April 282015 & Kebbi & In-house & Speaker and deputy & Breach of trust and embezzlement of members allowances & Successful \\
\hline April 292015 & Kebbi & Executive & Governor & $\begin{array}{l}\text { Violating section } 5(1)(a) \text { of the Kebbi State Budget } \\
\text { Monitoring and Price Intelligence Bureau Law, 2006, obtaining } \\
\text { a loan to the tune of } \mathrm{N} 2 \text { billion without confirmation by the }\end{array}$ & \\
\hline $99 / 2000$ & Sokoto & In-house & Deputy speaker & $\begin{array}{l}\text { Assembly among others misconducts } \\
\text { Incompetence }\end{array}$ & $\begin{array}{l}\text { Unsuccessful } \\
\text { Successful }\end{array}$ \\
\hline
\end{tabular}

The defective state system, inordinate ambitions of lawmakers, political intrigues and machinations by diverse interests fueled uncivil conducts amidst willingness on the part of legislators to compromise their collective commitment (Onuoha, 2006). In Anambra State for example, Anyaeche (2006) recalls how parallel governments exemplified by the trade unions, uncivil group and their ilk infiltrated the political space for action against the impeachment of Peter Obi (see number 8 Table 4).

Recounting Nigeria's legislative experience in the fourth republic 1999-2015, Bulus (2012) likens the wind of impeachment to a hurricane manifesting in sudden and often controversial changes in leadership and principal 
officers of the executive and legislative institutions particularly at the subnational level. As Table 1 to 6 reveal, Speakers, Deputy Speakers, Governors and their Deputies were all caught in the web of impeachment. On the positive side, impeachment became a reminder of the transient nature of political power vis-à-vis the need for representatives to be proactive and mandate-conscious in public service, accountability and representation. Representatives were made to be aware, albeit willy-nilly that their legitimacy and authority are derived from and dependent on popular mandate, the constitution, standing order and parliamentary ethics. Impeachment campaigns curtailed the excesses of elected officers who on assumption of office eventually got sucked into power contestation through unhealthy compromises that only guaranteed ephemeral political clouts. For example, Speakers and Deputy Speakers (see numbers $2,3,6,7,8,9$ and 10 of Table 5 and number 8 of Table 6 above) who were victims of impeachment campaigns were accused of negative dispositions that permeated their official engagements and that their political influence were at variance with parliamentary ethics, the institution of the legislature and legislators' core constitutional mandate (Bulus, 2012).

Table 4. South East

\begin{tabular}{|c|c|c|c|c|c|}
\hline Year & State & Institution & Victims officials & Grounds of impeachment/remarks & Outcome \\
\hline August 1999 & Abia & In-house & Speaker & Allegations of misconduct & Successful \\
\hline August 2000 & Abia & In-house & Speaker & Allegations of gross misconduct & Successful \\
\hline March 2003 & Abia & Executive & Deputy Governor & He resigned after 2 unsuccessful impeachment attempts & Successful \\
\hline February 2006 & Abia & Executive & Deputy Governor & Impeached in controversial circumstances/institutional politics & Successful \\
\hline August 72010 & Abia & Executive & Deputy Governor & $\begin{array}{l}\text { Willfully absenting himself from office, consistently and } \\
\text { willfully refused to attend state functions without lawful excuse etc. }\end{array}$ & Successful \\
\hline 2003 & Anambra & In-house & Speaker & Politics/allegations of gross misconduct & Successful \\
\hline September 2003 & Anambra & Executive & Deputy Governor & $\begin{array}{l}\text { For conduct unbecoming of a Deputy } \\
\text { Governor proclaiming himself Governor }\end{array}$ & Successful \\
\hline November 22006 & Anambra & Executive & Governor & Eleven impeachable offences tagged gross misconduct & Successful \\
\hline December 212011 & Ebonyi & In-house & Speaker. & Fraud, incompetence, dictatorial and abuse of office & Successful \\
\hline July 212014 & Ebonyi & In-house & Speaker & Incompetence and constitutional breaches & Successful \\
\hline February 182015 & Ebonyi & Executive & Governor & Constitutional breaches & Unsuccessful \\
\hline $99 / 2000$ & Enugu & In-house & Speaker & Inefficiency and "acts of impropriety and highhandedness & Successful \\
\hline August 262014 & Enugu & Executive & Deputy Governor & Running poultry in official quarters & Successful \\
\hline May 2015 & Enugu & In-house & Speaker & $\begin{array}{l}\text { Allegations of forgery, inflation of funds for state project } \\
\text { execution and unlawful acquisition of public landed property. }\end{array}$ & Successful \\
\hline May 42015 & Enugu & Executive & Governor & $\begin{array}{l}\text { Controversial accusation of high handedness and corrupt } \\
\text { enrichment, forging the } 2012 \text { supplementary appropriation of } \\
\text { the state amounting to N12 billion }\end{array}$ & Unsuccessful \\
\hline 2014 & Imo & Executive & Deputy Governor & Demanded and received financial gratification from contractor & Successful \\
\hline 1999 & Imo & In-house & Speaker. & N/A & Successful \\
\hline 1999 & Imo & In-house & Speaker & N/A & Step down \\
\hline
\end{tabular}

Table 5. South South

\begin{tabular}{|c|c|c|c|c|c|}
\hline Year & State & Institution & Victims officials & Grounds of impeachment/remarks & Outcome \\
\hline 2012 & Akwalbom & Executive & Deputy governor & Institutional politics/allegations of gross misconduct & Successful \\
\hline September 62000 & Akwalbom & In-house & Speaker & Incompetence, insensitivity and high handedness & Successful \\
\hline September 62000 & AkwaIbom & In-house & Deputy speaker & Incompetence, insensitivity and high handedness & Successful \\
\hline June 232005 & Akwalbom & Executive & Deputy governor & $\begin{array}{l}\text { Consumed by wind of politics alleging that each } \\
\text { lawmakers got } \$ 50,000\end{array}$ & Successful \\
\hline December 92005 & Bayelsa & Executive & Governor & $\begin{array}{l}\text { Allegations of corruption, money laundering, } \\
\text { misappropriation of public funds and abuse of office } \\
\text { alleged by the EFCC }\end{array}$ & Successful \\
\hline April 2008 & Delta & In-house & Speaker & $\begin{array}{l}\text { Visiting President Olusegun Obasanjo without the } \\
\text { prior approval of the Assembly }\end{array}$ & Successful \\
\hline March 2014 & Delta & In-house & Speaker & Resigned due to politics & Resigned \\
\hline $99 / 2000$ & Edo & In-house & Speaker & Politics/allegation of misconduct & Successful \\
\hline February 222010 & Edo & In-house & Speaker and deputy & Politics/allegation of misconduct & Successful \\
\hline June 102014 & Edo & In-house & Speaker & $\begin{array}{l}\text { Suspended by } 9 \text { minority members preparatory to } \\
\text { Governors impeachment leading to } \\
\text { counter-suspensions }\end{array}$ & Fragmented \\
\hline June 252014 & Edo & In-house & Deputy speaker & Misconduct and misdemeanour & Successful \\
\hline June 2013 & Rivers & In-house & Speaker & Subservience & Stalemated \\
\hline July 2013 & Rivers & Executive & Governor & Highhandedness & Stalemated \\
\hline June 192014 & Rivers & Executive & Governor & Highhandedness & Stalemated \\
\hline
\end{tabular}


In some cases, impeachment was predicated on the need to sanitize and benchmark representative institutions against minimum standards for quality representation. For example, Adamawa, Bauchi and Borno States (see number $1,3,5,7$ and 8 of Table 2) at different times removed their principal officers on breaches that included inaccessibility, arrogance and constant romance with their respective executives, incompetence and lack of administrative acumen. On the realization that the destiny of their State rested on the capacity of the state assembly to function effectively, Kano State lawmakers impeached an inexperienced but somewhat 'elderly' Speaker (see 2 Table 3). The State lawmakers initially thought the Speaker would bring his age to bear and learn faster on the job overtime. They also thought the ousted Speaker would help to facilitate institutional cohesion and effectively bridge possible relationship gap between the legislature and the executive. Conversely, the Speaker was accused of undermining the Assembly, as his ineffectiveness was held responsible for the disunity among the 40-member Assembly of which 32 eventually endorsed his impeachment for gross incompetence (Bulus, 2012).

Impeachment, by commission served as a major deterrent to purported abuses, breaches and misconduct by redefining the political character of prospective elective public office holders in official conducts in future political engagement. For example, Bulus (2012) reported that a former Speaker of Ebonyi State House of Assembly (see number 9 Table
4) was purportedly removed from office by overwhelming majority on allegation of fraud, incompetence and abuse of office. He was also accused of exhibiting dictatorial tendencies with plethora of bitter squabbles with the clerk of the State Assembly on issues of supremacy that set the Speaker and the Clerk on an infectious collision course. The speaker was impeached in line with section 92 subsections 2 (c) of the 1999 Constitution. One of the lawmakers, who also moved the motion for the Speaker's impeachment, (A member of the Assembly representing Onicha East Constituency) recalled that various sums of money were withdrawn, misappropriated and embezzled by the Speaker. He further lamented that his colleagues found it appalling that an individual could singlehandedly appropriate their collective interests in such a manner without due recourse to the law and operational guidelines of the Assembly.

Impeachment campaigns also helped to keep executive officials on their toes. For example, following the successful impeachment of some State Governors and similar campaigns in other states, considerable mutual respect by public officials across institutions in the three arms of government was discernible. Particularly hit by the new development were State Governors, who embarked on massive reviews of their relationships with their State Assemblies, the judiciaries and in some cases the Presidency (The presidency was the suspected mastermind of many impeachment campaigns against serving State Governors for one reason or the other).

Table 6. South West

\begin{tabular}{|c|c|c|c|c|c|}
\hline Year & State & Institution & Victims officials & Grounds of impeachment/remarks & Outcome \\
\hline July 71999 & Ekiti & In-house & Speaker & Institutional politics & Resigned \\
\hline September 272005 & Ekiti & Executive & Deputy Governor & $\begin{array}{l}\text { Caught in his quest to cause division among the state lawmakers, } \\
\text { falsely accused the lawmakers of receiving a bribe of two million } \\
\text { naira each from the governor to impeach him bringing their } \\
\text { integrity and reputation into disrepute and threatening to pull } \\
\text { down the government of Ekiti should his position be threatened. }\end{array}$ & Successful \\
\hline October 162006 & Ekiti & Executive & Governor and deputy & $\begin{array}{l}\text { Corruption, abuse of office, illegal operation of foreign } \\
\text { accounts; illegal diversion of local government funds; receipt of } \\
\text { illegal gifts and illegal transfer of the sum of } \$ 100,000 \text { to } \\
\text { the USA. The Governor and his deputy were for gross } \\
\text { misconduct alleged by the EFCC. }\end{array}$ & Successful \\
\hline November 172014 & Ekiti & In-house & Speaker and deputy & Politics/allegation of misconduct & Fragmented \\
\hline December 2002 & Lagos & Executive & Deputy governor & Politics/allegation of misconduct & Successful \\
\hline May 102007 & Lagos & Executive & Deputy governor & $\begin{array}{l}\text { Grave misconduct, insubordination and betrayal of trust } \\
\text { and confidence. }\end{array}$ & Successful \\
\hline 2014 & Ogun & Executive & Governor & Reckless borrowing from banks at high commercial interest rates & Unsuccessful \\
\hline 2014 & Ogun & Sub leg & Speaker & $\begin{array}{l}\text { Withheld House's allocation and unilaterally extended the } \\
\text { resumption indefinitely }\end{array}$ & Unsuccessful \\
\hline May 162008 & Ogun & In-house & Speaker and deputy & Subservience/rubber-stamp & Successful \\
\hline September 62010 & Ogun & In-house & Speaker and deputy & Highhandedness & Fragmented \\
\hline 2015 & Ondo & Executive & Deputy governor & Corruption/gross misconduct & Successful \\
\hline November 2000 & Osun & Executive & Governor & 22 impeachable offences & Unsuccessful \\
\hline December, 132002 & Osun & Executive & Deputy governor & Breach of oath of office and conflict of interests & Successful \\
\hline November 241999 & Oyo & In-house & Speaker & Politics/allegation misconduct & Successful \\
\hline January 122006 & Oyo & Executive & Governor & Corruption and financial misappropriation & Successful \\
\hline
\end{tabular}

Keys: In-house State House of Assembly

Note: Activities of many State Assemblies were under reported. Hence, the above list is not exhaustive as it only features most of the widely reported cases of intra and inter-institutional impeachment campaigns. In all, there were 76 reported cases of impeachment campaigns.

Source: Muheeb (2016a) 
Table 7. Breakdown of findings

\begin{tabular}{|c|c|c|c|c|c|c|c|c|}
\hline $\mathrm{S} / \mathrm{N}$ & Description & $\mathrm{NC}$ & $\mathrm{NE}$ & NW & SE & SS & SW & Total \\
\hline \multicolumn{9}{|c|}{ Victims } \\
\hline 1 & In-House & 10 & 5 & 7 & 9 & 9 & 6 & \\
\hline \multirow[t]{2}{*}{2} & Against executive & 4 & 3 & 1 & 9 & 5 & 9 & \\
\hline & Total & 14 & 8 & 8 & 18 & 14 & 15 & 77 \\
\hline \multicolumn{9}{|c|}{ Outcomes } \\
\hline 1 & Successful & 9 & 6 & 5 & 15 & 9 & 9 & \\
\hline 2 & Unsuccessful & 2 & 1 & 2 & 2 & - & 3 & \\
\hline 3 & Resigned & 3 & 1 & 1 & - & 1 & 1 & \\
\hline 4 & Stalemated & - & - & - & - & 3 & - & \\
\hline 5 & Step down & - & - & - & 1 & - & - & \\
\hline \multirow[t]{2}{*}{6} & Fragmented & - & - & - & - & 1 & 2 & \\
\hline & Total & 14 & 8 & 8 & 18 & 14 & 15 & 77 \\
\hline \multicolumn{9}{|c|}{ Period } \\
\hline 1 & $1999-2003$ & 3 & - & 2 & 7 & 3 & 5 & \\
\hline 2 & $2003-2007$ & - & - & & 3 & 2 & 4 & \\
\hline 3 & $2007-2011$ & - & 1 & & 1 & 2 & 2 & \\
\hline 4 & $2011-2015$ & 11 & 7 & 5 & 7 & 7 & 4 & \\
\hline \multirow[t]{2}{*}{5} & Date N/A & - & - & 1 & - & - & & \\
\hline & Total & 14 & 8 & 8 & 18 & 14 & 15 & 77 \\
\hline
\end{tabular}

Key: North-Central (NC), North-East (NE), North-West (NW), South-East (SE), South-South (SS) and South-West (SW)

NB: This Table 7 is a summary of all the previous tabulations above.

Similarly, Obineche and Onyejiuwa (2014) reported that the leadership of the All Progressives Congress (APC) specifically enjoined their serving Governors to forge and sustain cordial relationship with the Chief Judges of their states, who in the event of an order from the legislature to constitute a probe panel, may hide under any perceptible constitutional breach to frustrate such request. For example, the lingering moves to impeach Governor Rotimi Amaechi of Rivers State (see numbers 13 and 14 Table 5) and the attendant lobby for protection by the contending forces understandably extended to the judiciary. Thus, the prolonged nonappointment of a substantive Chief Judge for the State, after the disengagement from service of the erstwhile Chief Judge, Justice Iche Ndu was within this context attributed, perhaps to fears by Governor Amaechi that appointing Justice Daisy Okocha, who was believed to be the most senior judge of the State High Court and had the support of the presidency, might prove counterproductive in the long run.

Impeachment campaigns gave vent to multi-party politics. Lawmakers became increasingly aware of their bargaining advantage being in different political platform from their respective State executives. This played out effectively in Ogun, Imo, Edo and Ekiti States respectively. For example, Obineche and Onyejiuwa (2014) recall that Governor of Imo State, Rochas Okorocha was unable to get all the restive legislators of All Progressives Grand Alliance (APGA) and People's Democratic Party (PDP) extractions into his party's (APC)'s fold. Again, realizing that the stake was high, APGA was able to retained five out of its 11 lawmakers in the State Assembly against all odds. The leaderships of the two opposition parties (APGA and
PDP) in the State Assembly had a hold on their legislators, with a mandate to initiate impeachment proceedings, if considered necessary. As noted earlier, across the States, ruling parties were compelled to alert Governors on their respective platforms to court their respective legislatures to avoid being caught in the web of impeachments. The crisis of confidence that rocked the Edo State House of Assembly was linked to an impeachment attempt on the Speaker, Uyilgbe and Governor Adams Oshiomole by some recalcitrant APC lawmakers in collaboration with PDP members (see numbers 10 and 11 Table 5). Deft moves by the Governor and the APC majority in the State Assembly put the impeachment plot in disarray by depleting the ranks of the PDP lawmakers.

In Ogun State, the PDP made frantic efforts to exploit the intra-party crises that rocked the soul of the APCcontrolled government of the State. The intra-party crisis involving the State Governor and one of the party stalwarts and former Governor of the State, Segun Osoba percolated into the State Assembly with different factions. Obineche and Onyejiuwa (2014), again, recall that a faction led by Segun Osoba engaged another faction loyal to Governor Ibikunle Amosun. Intervention by leaders of the APC to resolve the impasse and strengthen the bond of unity in the party failed, manifesting in hatched plans and impeachment campaign against the State Governor, Ibikunle Amosun. The Speaker, Suraj Adekunbi who was considered sympathetic to Amosun also incurred the wrath of his colleagues with impeachment threats. He was accused of withholding the State Assembly's allocation and unilaterally and preemptively extending the resumption date of the Assembly indefinitely ostensibly at the 
instance of the State executive (see number 8 Table 6). Governor Amosun was accused of committing 14 impeachable offences including reckless borrowing at high interest rates thereby mortgaging the future of the State (see number 7 Table 6). Deductively, the Speaker probably ordered the indefinite suspension of resumption of the Assembly to forestall further action on the impeachment campaign. The initial hope of a successful impeachment proceeding was dashed, as the 26-member Assembly suffered irreconcilable factionalization for the remaining period of the legislative term 2011-2015 (Obineche and Onyejiuwa, 2014) (Prior to the crisis of confidence, the Assembly was largely dominated by the ruling APC, before it suffered further split into factions. The pro Amosun and the pro Osoba groups were the two major factions in the State APC. During the 2011 elections, the defunct Action Congress of Nigeria (ACN) won 17 seats, while the Peoples Democratic Party (PDP) and the Peoples Party of Nigeria (PPN) had six and three members respectively. Soon after its inauguration, three PDP legislators defected to the ruling party ACN then, giving it a clear majority status of 20 members. Things fell apart with the emergence of the Amosun and Osoba factions as a result of internal wrangling that trailed the emergence of APC from the ashes of ACN, CPC, ANPP and a faction of APGA (Obineche and Onyejiuwa, 2014).

\section{Procedural Shortcomings of Impeachment Campaigns}

The foregoing does not negate palpable procedural shortcomings in the deployment of impeachment. For example, among many others, Nnochiri (2014) reported that the voiding of the impeachment of former Deputy Governor of Taraba State, Alhaji Sani Abubakar (see 11 Table 1) by the Supreme Court brought into focus the arbitrary deployment of impeachment. A seven-man panel of Justices of the Supreme Court, in a unanimous judgment, held that the Deputy Governor was illegally removed from office on the recommendation of a "Kangaroo panel" that denied the erstwhile Deputy Governor fair hearing. The Supreme Court ordered Abubakar's reinstatement, as the Deputy Governor of Taraba State forthwith. The Court held that the sevenman panel that purportedly investigated allegations leveled against the Deputy Governor including the alleged diversion of public funds, "merely played out a script previously prepared and handed over to the panel". It held that the conduct of the lawmakers was in breach of section 188 of the 1999 Constitution. It specifically declared illegal the conduct of the proceeding that heralded the impeachment, which it noted held at a guesthouse that belonged to the majority leader rather than the hallowed chambers of the State Assembly. In the lead judgment prepared by Justice Sylvester Ngwuta, the Court held that the undisputed facts of the case created the inevitable but disturbing impression that the panel was a mere sham and that the removal of Abubakar from office was a fait accompli as it were (Nnochiri, 2014).

In arriving at its judgment, the Supreme Court vacated the earlier judgment of the Court of Appeal Yola Division dated July 19, 2013, which had affirmed a previous verdict by the Taraba State High Court dated March 19, 2013. It reasoned that the lower court ought to have declared the entire proceedings of the panel null and void and of no legal or factual effect whatsoever so as to resolve the issue of denial of fair hearing in favour of the Deputy Governor, who was serving his second term as Deputy Governor of Taraba State under Governor Danbaba Suntai. He had gone to the apex court to challenge the legality of his impeachment by the Assembly. After his impeachment, Alhaji Garba Umar took over as the Deputy Governor of the state. However, following the involvement of Governor Suntai in an air accident that left him incapacitated, Umar took over as the Acting Governor of the state, a position he occupied until he was removed by the Supreme Court Nnochiri (2014). It would be recall that as Section 188 of the Constitution requires, consequent upon the resolution of the State Assembly, the Speaker had requested the Acting Chief Judge of the State to constitute a 7-member panel to conduct investigation into allegations leveled against the Deputy Governor (Members of the State Assembly had laid before the Speaker a notice of complaint of gross misconduct against the appellant. Subsequently, the Assembly passed a motion, pursuant to section $188(4)$ of the constitution, to investigate the allegations against the Deputy Governor (Nnochiri 2014). Although the Deputy Governor filed an Originating Summons restraining the panel from investigating him, the panel ignored subsequent court ruling against it. Following the refusal of the panel to allow him to call witnesses to prove his innocence, the appellant amended his suit before the court, contending that he was denied opportunity to effectively defend himself. While upholding the case of the appellant, the apex court noted that the Taraba Assembly, at the lower court, relied on an incomplete and edited report, to conclude that the appellant did not prove his denial of fair hearing (Nnochiri, 2014).

Likewise, the Yola Division of Federal Court of Appeal, Adamawa State nullified the impeachment of Former Governor Murtala Nyako (see number 4 Table 2) on 11th February 2016. Channels Television reported that a five-man panel of Appeal Court judges sitting in Yola nullified Nyako's impeachment by setting aside an earlier ruling of a lower court that upheld the impeachment. The Court ruled that the impeachment was not done in accordance with the provision of the law. The five judges unanimously ruled that the Adamawa 
State House of Assembly fragrantly abused the tenets of law and violated the fundamental rights of Nyako by removing him from office illegally while he was denied fair hearing in the impeachment proceedings. The Court maintained that Nyako was not served with an impeachment notice as stipulated by law before the legislators embarked on the impeachment process it described as "wrong, sad, unfortunate and unconstitutiona.l" It faulted the manner in which the State Assembly prosecuted the impeachment process by serving Nyako through a substituted means. The judgment also described the impeachment proceeding as "a sham and a kangaroo sitting" that was stage managed and cannot be allowed to stand (Ajayi, 2016; CT, 2016). The Adamawa State Attorney General and Commissioner for Justice, Bala Sangha argued to the contrary. In his response, Sangha described the judgement as an absurdity that can only empower a governor to evade being served notices of impeachment and the Assembly would appeal the matter (CT, 2016).

Threats of impeachment on unsubstantiated claims by lawmakers like the impeachment campaign against Governor Tanko Almakura of Nasarawa State in 2014 also exposed the limitation of this measure of control. This also applies to the removal of elected officials from office based on reports from compromised probe panels as alluded to in the case of Taraba State discussed above or externally-induced impeachment campaigns to settle political scores as alleged in such instances as Oyo (see number 15 Table 6), Plateau (see number 8 Table 1) and Adamawa (see number 2 and 4 Table 2) States (Ogaziechi, 2014; Solomon, 2014; Ukumba, 2014; Onyekpere, 2014). Most remarkable were impeachments on grounds of misconduct without recommendation of victims for further prosecution where necessary thereby leaving a lacuna, one of which was referenced in the case involving Governor Ayodele Fayose's 2006 impeachment as executive Governor of Ekiti State. Fayose's legal team successfully got the Supreme Court to practically discountenance his 2006 impeachment in 2015. All of these cases underscore haphazard deployment of impeachment (Muheeb, 2016c).

Some impeachment processes also witnessed reported disappearance of legislatures' symbol of authority, the mace from Assembly chambers often in mysterious circumstances and some were even broken during fracas among dissenting legislators (see numbers 12, 13 and 14 Table 5) just as Assembly complexes were frequently immersed in cold waves at the dawn of every impeachment campaigns. Bulus (2012) reiterates that lawmakers were accused of being induced and compromised to launch impeachment campaign against legislatures' principal officers as well as against executives. In the lead judgment of the Supreme Court in the case of Taraba State's erstwhile Deputy Governor (see number 11 Table 1) alluded to earlier, Justice
Sylvester Ngwuta regretted a most disturbing aspect of impeachment processes, which was the composition of probe panel. Justice Ngwuta delivered the lead judgment in the case involving the former Deputy Governor of Taraba State who had pursued his case to the apex court to seek redress and have his arbitrary impeachment quashed. Ngwuta observed that the compromising disposition of the panel of inquiry constituted by the State Chief Judge in line with section 188 of the Constitution were direct opposite of the professional ethics and integrity of some of its members. The Justice and his other colleagues particularly observed that although the 7-man probe panel included two barristers, one of which was the chairman; yet, the harm the panel deliberately perpetrated in the unlawful impeachment of the Deputy Governor was too weighty not to be brought to the attention of the Disciplinary Committee of the Nigerian bar (Nnochiri, 2014).

As noted elsewhere, speculations were also rife that the presidency promoted a number of impeachments that swept through Bayelsa (see number 5 Table 5), Oyo (see number 15 Table 6), Anambra (see number 8 Table 4), Plateau (see number 8 Table 1) and Ekiti (see number 3 Table 6) States between 2005 and 2006 prior to the 2007 general elections in what was believed to be the usual tradition preceding general elections. Obineche and Onyejiuwa (2014) reported that, former Minister of the Federal Capital Territory (FCT) and a national officer of the All Progressives Congress (APC), Mallam Nasir ElRufai once hinted that Governors Adams Oshiomhole of Edo state and Rotimi Amaechi of Rivers State were strategically targeted for impeachment prior to the 2015 general elections (These were Governors of some opposition-controlled States (Adamawa, Kwara, Ogun, Oyo, Lagos, Edo, Nasarawa and Rivers States). Going available reports (Ogaziechi, 2014; Solomon, 2014; Onyekpere, 2014; Oladesu, 2014; Ade-Adeleye, 2014; Adekunle, 2014; Barnabas, 2014a; Yusuf, 2014a; Danjuma, 2014; Olaifa, 2014; Yusuf, 2014b; Ndiribe, 2014), this insinuation was given fillip by the eventful impeachment of Governor Murtala Nyako of Adamawa State in June 2014 less than a year to the 2015 general elections (see number 4 Table 2). Perhaps, the impeachment was brought to bear to create favourable dynamics for the PDP in Adamawa and other States where their Governors had defected into the main opposition party, the All Progressives Congress (APC) against the 2015 polls. This was more so that Governor Tanko Almakura of Nasarawa State escaped impeachment by chance, as the State legislators could not substantiate their claims.

Similarly, the political intrigues that culminated in impeachment campaigns against Nyako in April 2008 (see number 2 Table 2) (Shortly after Nyako resumed office in April following his successful showing at 
February 2008 polls) were reportedly brought under control by the personal intervention of former President Umaru Yar Ádua. Nyako's subsequent relationship with the State legislature blossomed remarkably such that in March 2010, the State House of Assembly passed a vote of confidence on the Governor, referring to him as a "messiah" to the people of Adamawa State (Oladesu, 2014; Ade-Adeleye, 2014; Adekunle, 2014; Barnabas, 2014b; Yusuf, 2014a; Ndiribe, 2014). The Presidency was also reported to have contemplated the removal of Governor Kashim Shettima of Borno State from office with the support of his predecessor, Ali Modu Sheriff. This was in spite of serial denial of the rumored impeachment initiative by the Speaker of the State House of Assembly, Abdulkarem Lawan, exonerating the Governor of any wrongdoing and pledging the State Assembly's support to his administration. The indictment of the presidency was predicated on Shettima's incessant intransigence and criticisms of the presidency's seemingly shoddy handling of the increasingly terrifying Boko Haram insurgency. The Governor was thought to have backtracked on the perceived harsh disposition when he got wind of the impeachment plot. Governor Ibrahim Geidam of the neighboring Yobe State was also reported to have countered presidency's massive mobilization of the State Assembly members against his administration by courting the leadership of the legislature and pledging his office's robust co-operation with the restive lawmakers (Obineche and Onyejiuwa, 2014).

Obineche and Onyejiuwa (2014) assert further that the 2014 impeachment campaigns were largely, dress rehearsals for the PDP to position itself effectively ahead of the 2015 general elections. They noted for example that the presidency and the PDP considered Kano State as a "strategic State" and did not leave any stone unturned in their bid to annex it as gateway to other States in the North West zone in particular and the entire North in general. Their permutations were overshadowed by the political clout and astuteness of the State Governor, Rabiu Kwankwaso of APC. Although Kwankwaso had a hold on the State Assembly; yet, the PDP did not consider the State an entirely APC State. The combined efforts of Kwankwaso and other APC frontliners in the State were not considered formidable enough to completely rout pro-PDP sentiments and interests given Kano's intimidating pan-Nigerian settlement profile. The Governor of the neighbouring Jigawa State, Sule Lamido's political astuteness was brought to bear in the political equation. Prior to his purported expression of interest in the presidential seat in the 2015 elections, Lamido had thrown an ironclad around the State legislature, which made it impenetrable for the PDP's impeachment marshals.

A number of impeachment campaigns were also viewed as arm-twisting tactics by legislators to blackmail their victims into favourable compromises particularly on allowances and benefits among other politically related issues. While some impeachments were dropped as commitments were extracted, many others were pursued amidst irreconcilable differences largely on finances and perquisites of offices. For example, as noted earlier, Obineche and Onyejiuwa (2014) reported that the Speaker of Ogun State Assembly was threatened with impeachment for allegedly withholding his colleagues' allowances (see number 7 Table 6). The impeachment threat against Imo State Governor, Rochas Okorocha was dropped on promises of prompt release of lawmakers' allowances. His counterparts, Governor Ibrahim Geidam of Yobe State successfully was able to regained the confidence of the lawmakers and warded the presidency off any possible mobilization of the State Assembly against his administration with promises of upward review of their salaries and allowances in addition to renew commitment to strengthening the liaison office between the two institutions. Governor Jonah Jang of Plateau State also contended with a restive PDP dominated State assembly over welfare issues. The brewing storm simmered with favourable terms of settlement between the State Assembly and the executive.

In their report, Obineche and Onyejiuwa (2014) recall that intractable crisis visited the impeachment of Chukwuma Nwazunku, the substantive Speaker (see number 9 Table 5), Ebonyi State House of Assembly, as the Speakership became contentious between Chukwuma Nwazunku and another member, Helen Nwobashi who was elected as new Speaker in Nwazunku's stead. The assembly got fragmented following the purported impeachment of Nwazunku by 18 of the 24-member Assembly as early as 6.00 am (Followed by subsequent election of Nwobashi as the Speaker). Thus, with each of the two contenders laying claim to speakership of the assembly, members were factionalized into two groups with each holding separate sitting in different locations. The Assembly members (pro-impeachment group) had accused Nwazunku of incompetence, misappropriation of funds and constitutional breaches including the fact of the assembly holding sitting for 71 times in violation of section 104 of the Constitution, which provides that the State Assembly must sit for a minimum period of 181 days in a year. Nwazunku who insisted on being the substantive Speaker at the material time countered his impeachment as illegal and an act of criminality, as the assembly was on recess and was not officially reconvene. The Police authorities subsequently deployed armed personnel to the Assembly complex to forestall possible unauthorized access into the Assembly chamber by either of the camps to conduct legislative business in a manner capable of causing breakdown of law and order typical of such circumstances. 


\section{Concluding Remarks}

By and large, the threat of impeachments will remain a recurring phenomenon given its potential and centrality in political and power contestations. This author aligns with the view that impeachment, as a process to set aside the will of the electorate is too serious a matter to be conducted as a matter of course without adhering strictly to due process. Therefore, to mitigate its arbitrary deployment and reduce its incidence, it is the responsibility of the judiciary to guard the procedure for impeachment jealously. As Justice Sylvester Ngwuta observed, if the matter is left at the whims and caprices of politicians and their panels, a State or even the entire country could be reduced to the status of a Banana Republic (Nnochiri, 2014). Former Ebonyi State Governor, Martin Elechi's cautionary note to the legislators also suffices to the effect that Assembly members must enjoy unfettered right to effect changes in their leadership as they deem fit. Such right must however be exercised responsibly and in conformity with the Constitution. In making changes, legislators must ensure that the integrity, dignity and honour of the legislative institution are preserved so as not to compromise the security of lives and property (Obineche and Onyejiuwa, 2014). The paper is a significant attempt at advancing the cause of institution building in particular and effective representative government general.

\section{Acknowledgement}

Profound gratitude to Akin Ajao (Concept Publications Limited, Lagos), Ibijoke LadeleAdeboyejo (Mrs.) and Diyal Manji Augustine, both of the Centre for Black and African Arts and Civilization (CBAAC), Lagos for their editorial assistance and secretariat suppoort.

\section{Funding Information}

The research on which this paper derived was a selfsponsored undertaking. Author neither receives any sponsorship support nor grant from any individual or organization.

\section{Authors' Contributions}

This paper by Ibraheem O. Muheeb is a single author publication.

\section{Ethics}

This article is original and contains unpublished material. The corresponding author confirms that all of the other authors have read and approved the manuscript and no ethical issues involved.

\section{References}

Ade-Adeleye, A., 2014. Nyako's Impeachment. 1st Edn., The Nation Newspaper, Lagos Nigeria, pp: 3.

Adekunle, Y., 2014. For ex-Adamawa governor, uncertain era beckons. The Nation Wednesday, Lagos.

Ajayi, A., 2016. Court of Appeal voids Nyako's impeachment. The Premium Times, Nigeria.

Anyaeche, C., 2006. The impeachment process of Gov. Peter OBI. Nigeriaworld.Com.

Barnabas, M., 2014a. Speaker sworn in as acting governor in Nyako's office. The Nation Wednesday, Lagos.

Barnabas, M., 2014b. How governor was impeached. The Nation Wednesday, Lagos.

Bulus, J., 2012. Hurricane Impeachment sweeps away Speakers. Vanguard Media Limited, Nigeria.

CT, 2016. Appeal court nullifies nyako's impeachment. Channels Television.

Danjuma, J., 2014. Panel dismisses charges against AlMakura. The Nation Truth in Defence of Freedom.

Desposato, S.W., 2004. Explaining Patterns of Oversight in Brazilian Subnational Governments. In: Legislatures and Oversight, Pelizzo, R. and R. Stapenhurst.

Hague, R. and M. Harrop, 1992. Comparative Government and Politics: An Introduction. 3rd Edn., Macmillan, New York, Basingstoke, ISBN-10: 0333558200, pp: 504.

Lijphart, A., 1992. Parliamentary Versus Presidential Government. 1st Edn., Oxford University Press, Oxford, ISBN-10: 0198780443, pp: 257.

Mgbe, J., 2013. The Impeachment of Jude Agbaso: Lessons from Gov. Peter Obi. Nigeriaworld.Com.

Muheeb, I.O., 2015. The legislature and representative government in Ogun state Nigeria, 1999-2011. Ph.D. Thesis, Department of Political Science, University of Ibadan.

Muheeb, I.O., 2016a. The Legislature and Party Politics in Nigeria's Fourth Republic. 1st Edn., Concept Publications Limited, Lagos.

Muheeb, I.O., 2016b. Characterizing Nigeria's Fourth Republic Legislature (1999-2015), Occasional Paper series, No. 78. The Centre for Advanced Studies of African Society (CASAS), Cape Town (University of South Africa) South Africa.

Muheeb, I.O., 2016c. "The Nigerian legislature and the political economy of obasanjo presidency. Afr. J. Politics Society. 2: 5-35.

Ndiribe, O., 2014. We punished Nyako for his arrogance-Kumdisi, Adamawa House whip. Vanguard Media Limited, Nigeria.

Nnochiri, I., 2014. S-Court reinstates impeached Taraba Deputy Governor. Vanguard Media Limited, Nigeria.

Nyong, B.E., 2000. Relationship among the Three Arms of Government for a Sustainable Democracy in Nigeria. In: Civil Society and the Consolidation of Democracy in Nigeria, Uya Okon, E. (Ed.), Institute of Public Policy and Administration, Calabar. 
Obineche, C. and G. Onyejiuwa, 2014. Impeachment frenzy: Lawmakers break loose.

Ogaziechi, N., 2014. As impeachment whirlwind blows. Independent Newspapers Limited.

Oladesu, E. 2014. Nyako's Travails...From Genesis to Revelation. The Nation Newspaper, Lagos Nigeria.

Olaifa, B., 2014. Panel's clearance has vindicated me-Al Makura. The Nation Truth in Defence of Freedom.

Onuoha, E., 2006. Re: The Impeachment Process of Gov. Peter Obi. Nigeriaworld.Com.

Onyekpere, E., 2014. Matters arising from the impeachment gale.
Solomon, K., 2014. Abuse of impeachment under 1999 Constitution. The Nation Truth in Defence of Freedom.

The 1999 Constitution of the Federal Republic of Nigeria. Federal Government Press, Lagos.

Ukumba, I., 2014. Impeachment: Al-Makura looks set to go. National Mirror.

Yusuf, A., 2014a. Nyako vows to fight his impeachment in court. The Nation Wednesday, Lagos.

Yusuf, A., 2014b. Impeachment: Al-Makura Waives Immunity, to Appear before Panel Monday. The Nation Truth in Defence of Freedom. 